\title{
PEMBERDAYAAN NELAYAN BERBASIS PENDIDIKAN EKONOMI DAN POTENSI PESISIR DI KABUPATEN MINAHASA UTARA
}

Artikel Penelitian

\section{Edwin Wantah ${ }^{1}$}

${ }^{1}$ Fakultas Ekonomi, Universitas Negeri Manado

Diterima 8 November 2017, Dipublikasikan 31 Oktober 2017

\begin{abstract}
Abstrak
Artikel penelitian ini bertujuan melakukan analisis kebutuhan pemberdayaan nelayan tradisional pesisir di Kabupaten Minahasa Utara Propinsi Sulawesi Utara berbasis pada pendidikan ekonomi dan potensi pesisir. Penelitian ini menggunakan rancangan penelitian deskriptif kualitatif dengan menggunakan metode survey, observasi lapangan, wawancara dan Focus Group Discussion (FGD). Subjek penelitian adalah nelayan pesisir Minahasa Utara berjumlah 40 orang nelayan yang tersebar pada 3 kecamatan yaitu Kecamatan Likupang Timur, Kecamatan Kema Dan Kecamatan Wori Kabupaten Minahasa Utara Yang memiliki kapasitas tangkap 5 Gross Ton ke bawah. Hasil analisis kebutuhan di identifkasi dalam observasi, wawancara mendalam serta Focus group Discussion yang di konfirmasi dengan hasil survey menunjukan $85 \%$ nelayan membutuhkan pengetahuan dan pemahaman mengenai karakteristik, sikap dan prinsi-prinsip menjadi seorang wirausahawan sukses yang dapat di implementasikan dalam aktifitas usaha produktif di pesisir, $90 \%$ membutuhkan pengetahuan mengenai diversifikasi usaha yang berbasis pada potensi pesisir dan laut (usaha alternatif nelayan), 90\% menyatakan bahwa mereka membutuhkan pengetahuan dan pemahaman mengenai pengolahan produk olahan ikan sebagai potensi pesisir dan laut, karena bahan baku yang melimpah, $80 \%$ menyatakan membutuhkan literasi mengenai bagaimana membangun kemitraan usaha dan jejaring usaha dengan kelompok usaha yang lain, 90\% menyatakan bahwa mereka membutuhkan literasi mengenai pembentukan kelompok usaha bersama (KUB) nelayan serta bagaimana mengembangkan kelompok usaha tersebut. 92, 5\% Nelayan membutuhkan literasi mengenai modal usaha dan tatacara mengakses modal usaha dan $85 \%$ menyatakan bahwa mereka sangat membutuhkan pengetahuan mengelolah uang, merencanakan pengalokasian keuangan dan tata cara menabung yang benar
\end{abstract}

\section{Kata kunci}

Analisis Kebutuhan, Pemberdayaan Nelayan, Pendidikan Ekonomi, Potensi Pesisir

\begin{abstract}
This research article aims to analyze the needs of traditional coastal fishermen empowerment in North Minahasa Regency North Sulawesi Province based on economic education and coastal potential. This research uses descriptive qualitative research design using survey method, field observation, interview and Focus Group Discussion. Research subjects are coastal fishermen of Minahasa Utara amounting to 40 fishermen spread in 3 sub-districts of East Likupang Subdistrict, Kema District and Wori Sub-district of North Minahasa Regency which has capture capacity of 5 Gross Ton downward. The results of the needs analysis are identified in the observation, in-depth
\end{abstract}

${ }^{1}$ Surel korespondensi: laily. fitriawati@yahoo.com 
interviews and the Focus group Discussion which confirmed by the survey results showed that $85 \%$ of fishermen need knowledge and understanding of the characteristics, attitudes and principles to become successful entrepreneurs who can be implemented in productive activities in the coastal, $90 \%$ require knowledge of business diversification based on coastal and marine potentials (fishermen alternative business), $90 \%$ stated that they need knowledge and understanding of processing of fish processing products as coastal and marine potential, because of abundant raw materials, $80 \%$ requiring literacy on how to build business partnerships and business networks with other business groups, $90 \%$ stated that they need literacy on establishing a joint venture group of fishermen and how to develop the business group. 92, 5\% Fishermen need literacy on venture capital and access to venture capital and $85 \%$ say they are in need of money management, planning for proper financial allocations and saving procedures

\section{Keywords}

Needs Analysis, Fishermen Empowerment, Economic Education, Coastal Potential.

\section{A. Pendahuluan}

Masyarakat pesisir sejauh ini dianggap sebagai bagian dari kelompok masyarakat termiskin dan termarginalkan (Maria, dkk 2012). Kelompok masyarakat ini sebagian besar bekerja pada sektor perikanan atau berprofesi sebagai nelayan. Program pembangunan perikanan yang menitikberatkan pada pertumbuhan ekonomi lewat industrialisasi perikanan tangkap tidak selalu memberikan dampak positif terhadap pendapatan ekonomi nelayan kecil (Nazmar, 2012). Program pemberdayaan masyarakat pesisir merupakan keniscayaan bagi pembangunan sumberdaya pesisir secara komprehensif (Maria, dkk 2012). Salah satu gagasan proses pemberdayaan tersebut adalah melalui pengembangan sumberdaya manusia yang pada gilirannya mampu mengelola sumberdaya lingkungan pesisir yang mereka geluti selama ini.

Pada dasarnya masyarakat pesisir memiliki karakteristik yang beragam, akan tetapi secara umum bekerja sebagai nelayan dengan berbagai tingkat teknologi perikanan yang digunakan. Mata pencaharian masyarakat pesisir dominan pada sektor pemanfaatan sumber daya kelautan (marine based resources) yaitu nelayan, petani ikan budidaya tambak dan laut (Fauzi, 2000). Karakteristik lainya adalah sebagian besar nelayan pesisir adalah nelayan tradisional yang umumnya memiliki ciri sama, yaitu tingkat pendidikan yang masih rendah, karena mereka menganggap tidak perlu pendidikan tinggi untuk mencari ikan dilaut dan lebih mementingkan atau mengandalkan tenaga serta pengalaman mereka (Maria, dkk. 2012). Dengan tingkat pendidikan yang rendah maka nelayan mengalami kesulitan untuk beralih profesi diluar profesinya sebagai nelayan.

Kemiskinan dan keterbatasan ekonomi yang menjadi persoalan utama nelayan pesisir khususnya nelayan tradisional diakibatkan banyak faktor. Selain faktor tingkat pendidikan yang rendah, faktor lainnya yaitu alam seperti cuaca dan musim tangkap ikan, faktor teknologi penangkapan ikan yang masih sangat sederhana, persaingan dengan nelayan modern atau korporasi perikanan, biaya melaut yang tinggi diakibatkan oleh mahalnya sarana dan prasarana produksi, harga bahan bakar minyak untuk melaut yang tinggi, ketergantungan nelayan tradisional pada rentenir atau tengkulak ikan, tidak adanya alternatif mata pencaharian lain selain sebagai nelayan tradisional, pendapatan ekonomi nelayan tradisional yang tidak menentu dan jauh dari kehidupan yang layak (Ferdriansyah dalam Indarti dan Wardana, 2013).

Penyebab kemiskinan nelayan diakibatkan juga oleh faktor-faktor ekstenal dan internal. Kusnadi (2003) menyatakan bahwa kemiskinan nelayan diakibatkan faktor internal yaitu keterbatasan kualitas sumber daya manusia nelayan, keterbatasan modal usaha, keterbatasan teknologi penangkapan, hubungan kerja pemilik perahu tangkap dan nelayan serta buruh nelayan yang kurang harmonis, ketergantungan pada musim melaut, dan gaya hidup atau perilaku konsumtif nelayan. Untuk faktor eksternal Kusnadi (2005) menyatakan bahwa persoalan kemiskinan nelayan banyak diakibatkan oleh kebijakan pembangunan perikanan yang masih belum berpihak pada nelayan, sistem pemasaran hasil perikanan yang hanya menguntungkan pedagang perantara, serta masalah kerusakan ekosistem laut lewat 
pencemaran air laut, pengrusakan terumbu karang, penggunaan alat tangkap yang tak ramah lingkungan, terbatasnya teknologi pengolahan pasca panen dan terbatasnya peluang kerja disektor non perikanan (off fishing) di desa-desa nelayan. Kehidupan nelayan masih menggantungkan nasib kepada hasil laut, yang semakin sulit sebagai sarana para nelayan memperbaiki kualitas hidupnya. Persoalan tingkat pendidikan masyarakat pesisir dalam hal ini nelayan pesisir seringkali menjadi persoalan utama kemiskinan nelayan. Dengan tingkat pendidikan yang rendah maka nelayan mengalami kesulitan untuk beralih profesi diluar profesinya sebagai nelayan. Perlu diketahui pendidikan sangat mempengaruhi kualitas sumber daya manusia nelayan (Udon, Tipyan, 2014).

Secara sosial ekonomi, wilayah pesisir dan laut memiliki arti penting dalam pembangunan nasional karena sebagian besar wilayah Negara Kesatuan Republik Indonesia adalah wilayah laut. Sekitar 75 persen wilayah Indonesia adalah perairan, dengan jumlah pulau 17. 508 pulau yang merupakan negara kepulauan terbesar di dunia dan dengan panjang garis pantai kedua terpanjang setelah kanada yaitu 81. $000 \mathrm{~km}$. Dengan diapit oleh dua benua asia dan australia dan dua samudera yaitu pasifik dan hindia menjadikan Indonesia sebagai suatu negara yang sangat strategis serta memiliki kekayaan alam laut yang melimpah mulai berbagai jenis ikan, mineral, terumbu karang yang beraneka ragam, minyak bumi serta banyak lagi kekayaan laut lainnya (Apridar, dkk 2011). Potensi sumber daya maritim yang melimpah ini kemudian tidak diikuti dengan adanya peningkatan kesejahteraan masyarakat pesisir pantai dan laut, sebagai akibat dari adanya pengelolahan sumber daya laut yang belum maksimal dan berpihak pada masyarakat pesisir. Potensi sumber daya pesisir yang melimpah juga di miliki oleh Kabupaten Minahasa Utara Propinsi Sulawesi Utara, tetapi belum di kelola maksimal sehingga belum banyak berdampak bagi pendapatan nelayan pesisir.

Permasalahan-permasalahan yang di hadapi oleh masyarakat pesisir dalam hal ini nelayan pesisir di wilayah lainya di Indonesia, dialami juga oleh nelayan pesisir yang ada diKabupaten Minahasa utara. Selain pendapatan rendah dan sangat tergantung musim ikan, permasalahan yang dihadapi oleh nelayan pesisirkhususnya nelayan tradisional di Kabupaten Minahasa utara terkendala dengan mahalnya biaya sarana prasarana nelayan, harga bahan bakar untuk melaut yang tinggi, umumnya dari nelayan ini terlilit dengan hutang pada rentenir atau pemberi pinjaman dan banyak dari mereka juga telah meminjam uang dan harus dikembalikan atau diganti dengan hasil tangkapan ikan, teknologi penangkapan ikan yang sederhana, teknologi pasca panen pengolahan ikan yang masih sederhana, kelembagaan ekonomi nelayan dan permodalan yang tidak ada, akses terhadap pasar yang belum memadai, kecenderungan nelayan tradisional menghasilkan jenis ikan yang relatif sama dengan nelayan moderen sehingga ketika over produksi harga ikan nelayan tradisional menjadi jatuh akibat mereka hanya biasa menjual pada pedagang ikan (tibo) dengan harga murah, kemudian persoalan perilaku konsumtif yang masih tinggi dikalangan masyarakat minahasa utara (orang tonsea).

Perilaku konsumtif tinggi juga terjadi di dalam keluarga nelayan pesisir di Kabupaten Minahasa utara. Perilaku konsumtif terjadi ketika para nelayan memiliki pendapatan yang lebih dari hasil melaut, dihabiskan dengan adanya syukuran, membeli barang-barang yang bukan prioritas dan tidak produktif. Kelebihan pendapatan tidak pernah ditabung. Hal ini terkait dengan financial literacy dari keluarga-keluarga nelayan tradisional pesisir ini yang masih rendah. Pengetahuan tentang alokasi yang efisien pendapatan dari hasil dari melaut yang masih rendah. Masalah lainnya adalah rata-rata nelayan tradisional, ketika tidak melaut hanya mengandalkan tenaga sebagai buruh nelayan bagi pemilik kapal (pajeko) dan korporasi atau perusahan pemilik kapal tangkap dengan upah yang sangat kecil. Buruh nelayan dalam sistem kelas sosial masyarakat pesisir tergolong kelompok masyarakat yang marjinal dan tertindas secara ekonomis (Apridar dkk, 2011).

Analisis kebutuhan pemberdayaan nelayan pesisir berbasis pendidikan ekonomi dan potensi pesisir di Kabupaten Minahasa Utara Propinsi Sulawesi Utara bertujuan untuk mengidentifikasi permasalahan serta kebutuhan-kebutuhan nelayan dalam rangka menjawab setiap permasalahan nelayan yang teridentifikasi pada komunitas nelayan pesisir Kabupaten Minahasa Utara. Analisis kebutuhan dilakukan sebagai dasar penyusunan materi model pemberdayaan nelayan pesisir Berbasis Pendidikan Ekonomi Dan Potensi Pesisir Kabupaten Minahasa Utara. 
46 | Edwin Wantah, Pemberdayaan Nelayan Berbasis Pendidikan Ekonomi Dan Potensi ...

\section{B. Metode Penelitian}

Penelitian ini merupakan suatu rangkaian awal atau tahapan awal dari 6 tahapan penelitian pengembangan model pemberdayaan nelayan pesisir berbasis pendidikan ekonomi di Kabupaten Minahasa Utara Propinsi Sulawesi Utara. Tahapan awal penelitian ini merupakan bagian dari tahapan design based research (DBR) dari model DBR yang diadopsi dari Reeves model, original design based research (2000) yang di kutip oleh Cotton. Wayne. dkk (2009). Tahapan design based research ini berisi 6 tahapan penelitian pengembangan. Dalam artikel ini akan di gambarkan hasil analisis kebutuhan model pemberdayaan nelayan pesisir Berbasis pada pendidikan ekonomi dan potensi pesisir

Penelitian ini menggunakan rancangan penelitian deskriptif kualitatif dengan menggunakan metode survey, observasi dan FGD untuk mengidentifikasi dan menganalisa perma-salahan dan kebutuhan nelayan pesisir terhadap model pemberdayaan yang berbasis pada pendidikan ekonomi dan pemanfaatan potensi pesisir dengan off fishing atau berbasis pada mata pencaharian selain menangkap ikan.

Subjek penelitian adalah nelayan pesisir yang berada di dua kecamatan yaitu Kecamatan Kema Dan Kecamatan Wori kabupaten Minahasa Utara dengan sampel penelitian berjumlah 40 Orang Nelayan tradisional dengan kapasitas tangkap 10 Gross ton kebawah. Untuk teknik pengumpulan data dan informasi penelitian, digunakan teknik observasi langsung, survey, wawancara mendalam dan lewat FGD. Peneliti melibatkan diri secara langsung dalam proses pengumpulan data dan informasi penelitian. Observasi langsung dilakukan oleh peneliti dan ahli pemberdayaan masyarakat untuk melihat aktifitas nelayan pesisir secara langsung. Untuk survey, disediakan angket pertanyaan yang di isi oleh nelayan pesisir. Sementara untuk metode FGD, peneliti melibatkan nelayan, fasilitator pemberdayaan serta tokoh masyarakat dan perwakilan dari dinas kelautan dan perikanan Kabupaten Minahasa Utara. Pada FGD di gali informasi mengenai permasalahan dan kebutuhan nelayan pesisir akan model atau program pemberdayaan nelayan berbasis pendidikan ekonomi dan pemanfaatan potensi pesisir berbasis off fishing.

Teknik analisa data menggunakan teknik analisis data deskriptif kualitatif dalam bentuk analisis persentase sederhana. Data yang di analisis lewat analisis peresentase lewat survey pada subjek penelitian diperkuat dengan hasil analisis dari wawancara mendalam dan hasil tanggapan serta masukan pada FGD.

\section{Temuan dan Diksusi}

Pada tahapan awal penelitian, peneliti melakukan identifikasi masalah dan analisis kebutuhan. Masalah dapat teridentifikasi berdasar masukan dari nelayan lewat observasi dan wawancara mendalam. Dari identifikasi persoalan nelayan pesisir, dapat di analisis dan di identifikasi kebutuhankebutuhan nelayan pesisir. Hasil Observasi dan wawancara mendalam kemudian di diskusikan lagi dalam kegiatan FGD untuk mengkonfirmasi kebutuhan-kebutuhan pokok mereka yang menjadi skala prioritas. Kegiatan tersebut dilakukan bersama kelompok nelayan, pemerintah, fasilitator pemberdayaan nelayan, dinas terkait dan akademisi pemerhati pemberdayaan nelayan. Setelah melakukan FGD, disusun lagi instrumen angket yang disebarkan pada sampel penelitian untuk mengetahui prioritas kebutuhan model pemberdayaan nelayan pesisir yang mereka butuhkan hasil identifikasi pada saat wawancara mendalam dan hasil FGD.

\section{Tingkat Pendidikan Nelayan}

Penelitian ini menggali informasi tentang tingkat pendidikan dari 40 orang nelayan pesisir yang ada di dua kecamatan yaitu kecamatan kema dan Kecamatan wori yang menjadi sampel penelitian. Data tingkat pendidikan formal dan tingkat pendidikan non formal yang pernah di ikuti nelayan berdasarkan survey lewat angket yang disebarkan kepada 40 orang nelayan yang tergabung dalam kelompok nelayan di dua kecamatan tersebut. Berikut disajikan dalam tabel latar belakang tingkat pendidikan dari 40 orang nelayan yang menjadi subjek penelitian.

Tabel 2 Latar Belakang Pendidikan Nelayan

\begin{tabular}{|c|l|l|l|l|l|l|l|l|}
\hline \multicolumn{4}{|c|}{ Pendidikan Formal (\%) } & \multicolumn{3}{|c|}{$\begin{array}{r}\text { Pendidikan Non } \\
\text { Formal (\%) }\end{array}$} \\
\hline A & B & C & D & E & F & G & H & I \\
\hline 0 & & 22, & & 17, & 0 & & & $5 \%$ \\
\hline
\end{tabular}

Sumber: Data Diolah Peneliti, 2017

Keterangan:

A: Tidak Sekolah

B: Tidak Lulus SD

C: Lulus SD

D: Lulus SMP

E: Lulus SMA

F: Lulus S1

G: Ikut Pelatihan

$\mathrm{H}$ : Tidak Pernah Ikut Pelatihan

I: Ikut Pendidikan Nonformal Lainnya 
Salah satu kendala dalam program pemberdayaan nelayan pesisir di Kabupaten Minahasa Utara yang dilakukan selama ini adalah pelatihan teknis dan pendidikan nonformal yang dilakukan belum menyentuh pada kebutuhan prioritas nelayan karena tidak dilakukan analisis kebutuhan terlebih dahulu sehingga tidak menjawab persoalan dan kebutuhan mereka.

\section{Pengetahuan, Literasi, dan Keterampilan Wirausaha}

Dalam menggali kebutuhan akan pengetahuan, literasi, keterampilan kewirausahaan bagi nelayan maka di himpun data lewat angket survey, FGD dan wawancara mendalam dengan kelompok nelayan yang ada. Dari data survey dapat dipaparkan $65 \%$ nelayan tidak pernah mengikuti pendidikan dan pelatihan sama sekali dan $30 \%$ yang pernah mengikuti pendidikan dan pelatihan, tetapi proses pendidikan dan pelatihan tersebut tidak menyentuh pada aspek membangun pengetahuan dan literasi serta keterampilan berwirausaha. Sementara $5 \%$ dari responden yang pernah mengikuti pendidikan dan pelatihan nonformal lainnya tidak berhubungan sama sekali dengan keterampilan kewirausahaan. Sehingga dapat disimpulkan sebagian nelayan pesisir Minahasa Utara khususnya yang menjadi objek penelitian ini belum memiliki pengetahuan, literasi serta keterampilan mengenai kewirausahaan. Dari hasil informasi yang didapatkan dalam FGD bahwa sebagian besar dari nelayan ingin memiliki mata pencaharian alternatif selain nelayan tangkap. Mereka menginginkan adanya pelatihan teknis berwirausaha serta adanya pendampingan dalam berwirausaha. Nelayan hanya terjebak pada satu jenis mata pencaharian yaitu menangkap ikan saja dan tidak ada usaha-usaha alternatif lainnya. Belum adannya diversifikasi usaha selain usaha tangkap, diakibatkan oleh pengetahuan dan keterampilan berwirausaha yang tidak dimiliki oleh nelayan pesisir di Kabupaten Minahasa Utara.

\section{Pengetahuan Membuat Produk Olahan Ikan}

Hasil observasi dan wawancara mendalam, peneliti menemukan bahwa sebagian besar nelayan tidak memiliki keahlian dan keterampilan dalam mengelolah ikan menjadi produk bernilai ekonomis tinggi. Dari hasil FGD yang dilakukan dengan kelompok nelayan dari Kecamatan Kema dan Wori, didapatkan informasi bahwa hasil produksi tangkap ikan sering melimpah tapi harga ikan menjadi murah dan nelayan mengalami kesulitan memasarkan ikan tangkapan, sementara nelayan dan keluarganya tidak memiliki keterampilan dan keahlian mengolah ikan menjadi produk-produk olahan pangan bernilai ekonomi tinggi serta tahan lama). Dari hasil Focus Group Discussion dan wawancara mendalam dapat disimpulkan bahwa kebutuhan akan produk olahan ikan sangat besar, produksi hasil tangkapan melimpah namun keahlian dan ketrampilan mengelolah produk olahan ikan yang bernilai ekonomi tinggi oleh nelayan dan keluarganya sangat minim.

\section{Pengetahuan Manajeman Keuangan}

Dari observasi yang dilakukan peneliti mengenai perilaku ekonomi keluarga nelayan, sebagian besar masih berperilaku konsumtif ketika mendapatkan penghasilan ataupun pendapatan dari hasil melaut. Hasil survey kepada sampel penelitian, 35\% nelayan yang pernah ikut pelatihan teknis tersebut namun tidak mendapatkan pelatihan mengenai pengelolahan keuangan keluarga nelayan. Hanya 5 persen nelayan yang pernah mengikuti pendidikan dan pelatihan nonformal lainnya yang pernah mengikuti pendidikan pengelolaan keuangan, akan tetapi tidak secara signifikan menguasai pengetahuan pengelolahan keuangan keluarga, sementara $65 \%$ dari sampel penelitian tidak pernah mengikuti pendidikan dan pelatihan termasuk pendidikan dan pelatihan pengelolaan keuangan keluarga nelayan.

Dari hasil diskusi dalam FGD yang melibatkan perwakilan kelompok nelayan di kecamatan Kema, dinas kelautan perikanan Kabupaten Minahasa Utara dan fasilitator pemberdayaan nelayan di dapatkan informasi bahwa sebagian nelayan pesisir Kecamatan Kema tidak mengetahui cara mengelolah keuangan keluarga mereka, belum pernah merencanakan alokasi anggaran pengeluaran dengan baik dan rata-rata dari mereka tidak memiliki tabungan dan investasi lainnya. Hasil kesimpulan FGD dengan sesi analisis kebutuhan nelayan pesisir di kecamatan Kema Kabupaten Minahasa Utara menyatakan nelayan membutuhkan pelatihan pengelolaan keuangan keluarga dalam rangka meningkatkan pengetahuan mereka tentang bagaimana mengelolah uang, termasuk bagaimana cara menabung yang baik serta melakukan investasi.

Pengetahuan nelayan terhadap akses modal pada lembaga keuangan ataupun koperasi yang 
48 | Edwin Wantah, Pemberdayaan Nelayan Berbasis Pendidikan Ekonomi Dan Potensi ...

menawarkan bunga ringan sangat minim. Hasil wawancara mendalam dengan nelayan Desa Lilang Kabupaten Minahasa Utara menyatakan bahwa selama ini modal untuk melaut hanya didapatkan lewat pinjaman kepada rentenir atau tuan perahu pajeko (kapal tangkap besar) atau kepada pedagang ikan, seringkali nelayan kesulitan mengembalikannya akibat bunga pinjaman yang terlalu tinggi, sehingga mereka sangat membutuhkan pinjaman modal usaha tangkap dan usaha pesisir lainnya dari pihak perbankan dengan skema pengembalian yang mudah, jangka waktu yang lebih fleksibel dan bunga pinjamaan yang kecil. Nelayan membutuhkan pemahaman mengenai modal usaha dan cara memperoleh bantuan kredit modal usaha dari perbankan. Temuan lain dari penelitian dari hasil wawancara mendalam dengan Anggota kelompok Nelayan Kecamatan Kema, yang mengatakan bahwa rata-rata modal melaut nelayan berasal dari pinjaman ke rentenir dengan bunga tinggi. Nelayan tidak tahu bagaimana mendapatkan modal usaha dengan bunga kecil ataupun tanpa bunga.

\section{Pengetahuan Diversifikasi Usaha}

Dari hasil observasi dan wawancara mendalam bahwa nelayan pesisir Minahasa utara sebagian besar tidak memiliki alternatif mata pencaharian lain selain sebagai nelayan tangkap, sehingga mekanisme bertahan hidup mereka sangat tergantung dari hasil tangkapan ikan dan hasil laut lainnya. Hasil wawancara dengan anggota Kelompok Nelayan Sarunta didapati bahwa ikan rucah (lompa) yang tidak bernilai ekonomis apabila di jual dalam bentuk ikan mentah. Walaupun dijual pasti dibeli dengan harga murah. Begitupun dengan limbah ikan, limbah kepiting (cangkang kepiting) yang banyak tersedia di pesisir hanya di buang dan tidak diolah. Beberapa usaha yang dapat dikembangkan oleh nelayan dan keluarganya, karena bahan bakunya tersedia yaitu pengolahan surimi ikan (gel ikan), bakso ikan, nugget ikan, kerupuk ikan, sambal dan abon ikan. Diversifikasi usaha pengolahan produk olahan berbahan baku ikan ini dapat dijadikan sumber usaha atau mata pencaharian lainnya bagi nelayan dan keluarganya. Hasil FGD dan Wawancara mendalam yang dilakukan peneliti, sebagian besar dari nelayan dan keluarga nelayan tidak memiliki keahlian mengolah produk olahan. Bentuk diversifikasi usaha lainnya yang dapat di kembangkan di pesisir Minahasa Utara adalah pengelolaan usaha Ekowisata pesisir oleh Nelayan.

\section{Kemitraan}

Salah satu temuan observasi dan wawancara peneliti di lokasi penelitian adalah sebagian besar nelayan yang ada di pesisir Minahasa utara tidak masuk dan terlibat aktif dalam organisasi atau kelompok nelayan. Rata-rata mereka berusaha secara individual dalam aktifitas nelayan. Meskipun mereka tidak terikat dalam kelompok, tetapi perilaku saling membantu, gotong royong, interaksi sosial yang kental sering dipraktekan dalam kehidupan sosial mereka baik antar nelayan maupun dengan kelompok lainnya seperti petani, pedagang dan kelompok masyarakat lainnya. Dari hasil FGD teridentifikasi bahwa mereka menginginkan membentuk kelembagaan usaha nelayan dalam bentuk kelompok usaha bersama nelayan karena dengan berkelompok atau membentuk kelompok formal nelayan mereka berhak atas bantuan sarana produksi dari pemerintah. Kendala yang mereka hadapi adalah bagaimana pengetahuan membentuk kelompok, pengesahan kelompok, administrasi kelompok, menyusun program kelompok termasuk pengetahuan dalam mengadopsi nilai budaya mapalus (gotong royong) dalam mengembangkan kelompok atau kelembagaan usaha nelayan.

Dari hasil FGD teridentifikasi nelayan tidak memiliki pengetahuan mengidentifikasi mitra usaha serta bentuk-bentuk kerjasama yang dapat dilakukan mereka dengan mitra usaha yang menguntungkan mereka. Dari hasil observasi, wawancara dan FGD yang dilakukan dapat disimpulkan nelayan membutuhkan pengetahuan mengenai membangun kemitraan usaha dan jejaring usaha, menjaga relasi usaha dengan mitra usaha dan pengetahuan tentang segala bentuk kerjasama usaha yang dapat dilakukan dari usaha-usaha berbasis pesisir dan laut yang direncanakan oleh kelompok nelayan.

Dari hasil analisis kebutuhan lewat survey yang dilakukan kepada nelayan dapat dipaparkan bahwa $85 \%$ nelayan membutuhkan pengetahuan dan pemahaman mengenai Ciri, karakteristik, sikap dan prinsip-prinsip menjadi seorang wirausahawan yang sukses yang dapat di implementasikan dalam pemberdayaan mereka sebagai nelayan pesisir, $90 \%$ nelayan subjek penelitian membutuhkan pengetahuan mengenai diversifikasi usaha yang berbasis 
pada potensi pesisir dan laut, 90\% nelayan membutuhkan pengetahuan dan pemahaman mengenai pengolahan produk olahan ikan karena bahan baku yang melimpah, $80 \%$ nelayan membutuhkan pemahaman mengenai bagaimana membangun kemitraan usaha dan jejaring usaha dengan kelompok usaha yang lain karena keterbatasan kemampuan dalam mengidentifikasi jenisjenis atau model kemitraan yang cocok dengan usaha yang mereka lakukan, 90\% nelayan membutuhkan pemahaman mengenai tatacara pembentukan kelompok usaha bersama nelayan serta bagaimana mengembangkan kelompok usaha tersebut, 92,5\% membutuhkan pemahaman mengenai modal usaha dan bagaimana mengakses modal usaha. $85 \%$ nelayan menyatakan membutuhkan pemahaman mengenai pengelolaan keuangan keluarga nelayan, perencanaan keuangan, pemahaman mengenai tabungan dan cara pengalokasian uang yang benar.

\section{Penutup}

1. Nelayan yang menjadi subjek penelitian ini memiliki latar belakang pendidikan formal, meski ada sekitar $15 \%$ yang tidak menyelesaikan sekolah dasar, kemudian persentase tingkat pendidikan yang terbesar adalah lulusan tingkat sekolah menengah pertama atau SMP dengan $45 \%$, di ikuti oleh lulusan SD sebesar $22,5 \%$ dan lulusan SMA sebanyak 17,5 persen. Secara umum seluruh nelayan yang menjadi sampel penelitian sudah dapat membaca dan menulis, sehingga memudahkan peneliti dalam pengambilan data lewat angket. Untuk latar belakang pendidikan nonformal berupa pendidikan dan pelatihan diluar kegiatan pendidikan formal, sebagian besar nelayan yaitu $65 \%$ belum pernah mengikutinya, 30\% pernah mengikuti pelatihan teknis dan 5 persen pernah mengikuti pendidikan nonformal lainnya yang tidak terkait dengan mata pencaharian mereka. Saran dari hasil penelitian ini sangat diperlukan pelatihan teknis terkait dengan pemanfaatan potensi pesisir seperti pengolahan produk olahan ikan berbasis zero waste production, pelatihan teknis mengenai mata pencaharian alternatif nelayan seperti budidaya ikan di lepas pantai, pengelolaan usaha ekowisata pesisir dan laut serta pelatihan teknis pemanfaatan potensi pesisir berbasis pada off fishing seperti budidaya ikan dan rumput laut.
2. Hasil survey analisis kebutuhan nelayan terdapat $85 \%$ nelayan sampel penelitian menginginkan adanya pendidikan dan pelatihan Sikap, ciri ciri, karakteristik dan prinsip wirausahawan yang sukses. Saran penelitian perlu adanya program pemberdayaan nelayan dengan bentuk pembelajaran dan pelatihan teknis pengolahan potensi pesisir yaitu ikan tangkapan nelayan menjadi produk-produk olahan bernilai ekonomis seperti surimi ikan, bakso ikan, nugget ikan, sambal ikan.

3. Hasil FGD dan survey terhadap nelayan mengenai kebutuhan akan model pemberdayaan nelayan berbasis pendidikan ekonomi dan potensi pesisir menyatakan bahwa $90 \%$ atau nelayan yang menjadi sampel penelitian menginginkan adanya diversifikasi mata pencaharian nelayan yang berbasis pada potensi pesisir tanpa harus bergantung dari hasil laut. Saran penelitian bagi nelayan untuk mengikuti pendidikan dan pelatihan mengenai pemanfaatan potensi pesisir lainnya seperti ekowisata pesisir dan laut, pertanian dan peternakan serta budidaya ikan dipesisir yang di integrasikan. Contoh bentuk integrasi perikanan pesisir, pertanian pesisir, peternakan pesisir adalah nelayan dapat berternak sambil menanam jagung dan ketela serta mencari ikan rucah sebagai bahan baku pakan ternak mereka. tepung jagung, tepung ikan rucah dan ketela pohon dapat di olah menjadi pakan berkualitas tinggi untuk hewan ternak nelayan seperti unggas.

4. Hasil survey analisis kebutuhan nelayan terdapat $90 \%$ nelayan sampel penelitian menginginkan adanya pendidikan dan pelatihan pengolahan produk olahan ikan. Pelatihan teknis wirausaha yang dibutuhkan adalah pengolahan ikan menjadi beberapa produk turunan seperti surimi ikan, bakso ikan, nugget ikan, sambal ikan. pelatihan teknis juga diarahkan pada bagaimana teknis pengemasan dan peningkatan kualitas produk olahan ikan menjadi produk bernilai ekonomi tinggi. Pelatihan lainnya yang dibutuhkan adalah pelatihan usaha pengelolaan ekowisata pesisir dan laut.

5. Salah satu temuan peneliti dari observasi dan wawancara mendalam yang dilakukan pada nelayan adalah, sebagian dari mereka tidak memahami bagaimana membangun kemitraan usaha nelayan dengan kelompok usaha ataupun 
50 | Edwin Wantah, Pemberdayaan Nelayan Berbasis Pendidikan Ekonomi Dan Potensi ...

mitra usaha yang lebih besar. Dalam FGD teridentifikasi juga persoalan mengenai ketidakmampuan nelayan dalam mencari dan menjalin kemitraan usaha dengan mitra usaha yang dapat menunjang usaha nelayan. Hasil survey mengenai analisis kebutuhan pemberdayaan nelayan di dapatkan bahwa $80 \%$ nelayan menginginkan adanya model pemberdayaan nelayan lewat pendidikan dan pelatihan tentang bagaimana membangun kemitraan usaha oleh nelayan dengan pihak lain yang saling menguntungkan. Saran penelitian bagi nelayan untuk dapat membangun jejaring kerja serta kemitraan dengan pihak lain baik individual, lembaga ekonomi maupun korporasi dalam rangka alih pengetahuan, jaringan pemasaran ikan dan produk olahan ikan, informasi pasar, bantuan modal usaha, bantuan teknologi serta berbagai jenis kerjasama kemitraan dengan mitra kerja nelayan.

6. Dari Hasil survey pada sampel penelitian bahwa $90 \%$ nelayan membutuhkan akan model pemberdayaan nelayan pesisir berbasis pendidikan ekonomi lewat pendidikan dan pelatihan pengelolaan keuangan keluarga nelayan. Saran penelitian bagi nelayan untuk dapat mengikuti pelatihan pengelolaan keuangan keluarga dan berperilaku hidup hemat. Saran lainnya, nelayan dapat memiliki tabungan untuk masa depan keluarga dan rencana jangka panjang serta merencanakan melakukan investasi lewat tabungan, investasi faktor-faktor produksi seperti perahu, alat tangkap, lahan pertanian di pesisir dan menghindari perilaku konsumsi yang berlebihan.

7. Temuan penelitian sebagian besar nelayan yang ada di pesisir Minahasa Utara tidak terlibat aktif dalam organisasi atau kelompok nelayan. Ratarata mereka berusaha secara individual dalam aktifitas nelayan. Meskipun tidak terikat dalam kelompok, tetapi perilaku saling membantu, gotong royong, interaksi sosial yang kental sering dipraktekan dalam kehidupan sosial mereka baik antar nelayan maupun dengan kelompok lainnya. Dalam FGD teridentifikasi bahwa nelayan kurang memiliki kemampuan dalam mekanisme pembentukan kelompok usaha bersama atau kelembagaan ekonomi nelayan. Hasil survey setelah dilakukan FGD menemukan bahwa $90 \%$ nelayan menginginkan adanya pelatihan mengenai bagaimana membentuk kelompok dan bagai- mana mekanisme pengesahan kelompok nelayan. Saran penelitian, nelayan perlu membentuk kelompok atau organisasi nelayan dengan tujuan untuk saling membantu dalam aktiftas melaut serta aktifitas produktif lainnya disekitar pesisir. Dengan berkelompok nelayan dapat saling tukar informasi dan pengetahuan serta tenaga dalam rangka meningkatan produktifitas dan pendapatan mereka.

8. Temuan penelitian bahwa sebagian besar nelayan tidak memiliki kemampuan dalam mengakses permodalan. Nelayan sering terjebak berhutang pada rentenir dengan bunga tinggi. Dalam menutupi biaya hidup keluarga serta biaya melaut nelayan sering terjebak pada hutang. Hasil survey analisis kebutuhan pemberdayaan nelayan pesisir menegaskan bahwa 92,5\% nelayan yang menjadi sampel penelitian setuju bahwa mereka menginginkan adanya pendidikan dan pelatihan mengenai tatacara mengakses permodalan serta jenis-jenis permodalan yang dapat diakses oleh nelayan. Saran penelitian agar perlu adanya pelatihan dan pendampingan intensif bagi kelompok-kelompok nelayan sehingga mereka memiliki pengetahuan dan kemampuan dalam mengakses modal usaha perikanan serta modal usaha lainnya yang digeluti nelayan.

9. Temuan penelitian sebagian besar nelayan tidak memahami mekanisme pengelolaan keuangan keluarganya. Rata-rata nelayan dan keluarganya tidak memiliki tabungan dan tidak tahu cara menabung di lembaga keuangan bank. $85 \%$ dari sampel penelitian menyatakan sangat membutuhkan pengetahuan dalam pengelolaan keuangan, merencanakan pengalokasian keuangan dan tata cara menabung yang benar. Saran penelitian perlu adanya pembelajaran dan pelatihan pengelolaan keuangan keluarga bagi nelayan dan keluarganya.

\section{E. Daftar Pustaka}

Akbar, S. 2007. Pembelajaran Nilai Kewirausahaan Dalam Perspektif Pendidikan Umum: PrinsipPrinsip Dan Vektor-vektor percepatan proses internalisasi Nilai Kewirausahaan. Penerbit Universitas Negeri Malang.

Apridar, M Karim, Suhana, 2011, Ekonomi kelautan Dan Pesisir, Graha IImu Jogyakarta 
Cotton Wayne, 2009. A Journey Through a Design Based Research Project, Research Online Faculty of Education and Faculty Of Social Science University Of Wollongong

Elfindri. 2002. Ekonomi Patron Client. Fenomena Mikro Rumah Tangga Nelayan Dan Kebijakan Makro. Andalas University Press

Evans, D. R. 1981, The Planning of nonformal education, Published in 1981 by The United Nations Educational, Scientific and Cultural Organization 7 Place de Fontenoy, 75700 Paris

Fauzi, S. 2000. Valuasi Ekonomi Sumberdaya Pesisir. Materi pada Seminar Pengelolaan Wilayah Pesisir dan Pulau-pulau Kecil Secara Berkelanjutan. Proyek Kerjasama IPB dengan The Papua New Guinea University of Technology.

Harunisya. N, 2014. Pendidikan Ekonomi Masyarakat Melalui Program Pemberdayaan Nelayan Kabupaten Probolinggo. Jurnal Ecobus Vol 1 No. 22014.

Hikmat A, 2006. Strategi Pemberdayaan Masyarakat, Humaniora Utama Press Bandung

Indarti I, \& Wardana DS, 2013. Metode pemberdayaan masyarakat pesisir melalui penguatan kelembagaan pesisir di Kota Semarang. BENEFIT Jurnal Manajemen dan Bisnis Volume 17, Nomor 1, Juni 2013, hlm. 7588

Jogiyanto. 2007, Sistem Informasi Keprilakuan. Penerbit, Andi Yogyakarta.

Kusnadi. 2005. Akar Kemiskinan Nelayan. Yogyakarta LKiS Pelangi Aksara

Kusnadi. 2009. Keberdayaan Nelayan Dan Dinamika Ekonomi Pesisir, Aruzz Media Yogyakarta

Marzuki. HMS, 2012, Pendidikan Nonformal, Remaja Rosdakarya, Bandung
Maria CA, dkk, 2012. Model Kurikulum pemberdayaan Masayarakat Nelayan Pesisir berbasis ekonomi produktif di Kabupaten Cirebon danKabupaten Jeneponto. Lembaga Riset Kementerian Kelautan dan Perikanan.

McArdle. J. 1989. Community Development Tools of Trade. Community Quarterly Journal 16: 47-54

Moedzakir, M. 2010. Metode Pembelajaran Untuk Program-Program PLS. Malang. UM Press

Morales. HN, et al, 2013. Empowerment as a Culture and a Strategy to Strengthen the Activities of Research and Inovation: proposal Of a Methodology, European Scientific Journal December 2013 /Special/ edition vol. 1 ISSN: 1857 - 7881 (Print) e - ISSN 1857- 7431

Mubarak, Z, 2010. Evaluasi Pemberdayaan Masayarakat Ditinjau Dari Proses Pengembangan Kapasitas pada kegiatan PNPM mandiri perkotaan didesa satrodirjan Kabupaten Pekalongan, Disertasi Pascasarjana Universitas Diponegoro, Semarang.

Nazmar E, 2012. Model Pemberdayaan Ekonomi Rumah Tangga Nelayan Skala Kecil Dengan Pengembangan Off Fishing di Kota Padang Sumatera Barat, Jurnal Ekonomi Manajemen Dan Akuntansi Vol 18 No 1 Juni 2018.

Soeprijadi. L. et al, 2013, Model Joint Business Group Based Knowledge for Fishermen Community Empowerment Strategies (Case Study of Business Diversification on Solid Capture Region Cirebon City) Business and Management Horizons ISSN 2326-0297 2013, Vol. 1, No. 1

Sumaryadi I N, 2005, Perancanaan Pembangunan Daerah Otonom Dan Pemberdayaan Masayarakat, Citra Utama, Jakarta.

Tipyan C, Udon, F. 2014 Dynamic livelihood strategies of fishery in ban don bay, Suratthani, Thailand, International Journal of Asian Social Science, 2014, 4(11): 1126-1138 